\title{
Absolute $\mathrm{p} K_{\mathrm{a}} \mathrm{s}$ of Sulfonamides in Ionic Liquids: Comparisons to Molecular Solvents
}

\author{
Zedong Wang, ${ }^{\dagger}$ Xin Li, ${ }^{\dagger}$ Pengju Ji, ${ }^{*}$ and Jin-Pei Cheng $*, \dagger, *$ \\ 'State Key Laboratory of Elemento-organic Chemistry, Collaborative Innovation Centre of Chemical Science \\ and Engineering, Nankai University, Tianjin, 300071, China. \\ ${ }^{\ddagger}$ Center of Basic Molecular Science (CBMS), Department of Chemistry, Tsinghua University, Beijing, 100084, \\ China. \\ E-mails: jipengju@mail.tsinghua.edu.cn; jinpei_cheng@mail.tsinghua.edu.cn
}

\section{Table of Contents}

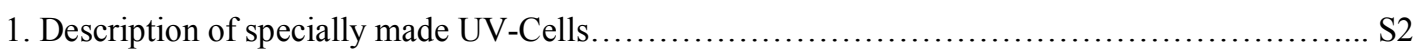

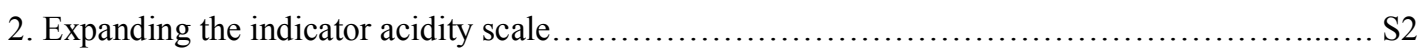

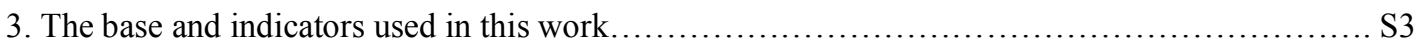

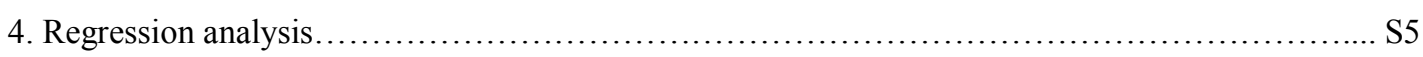

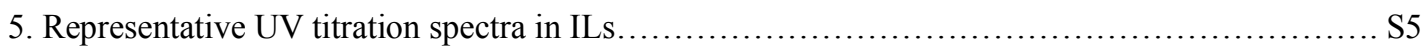

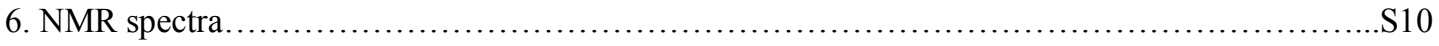

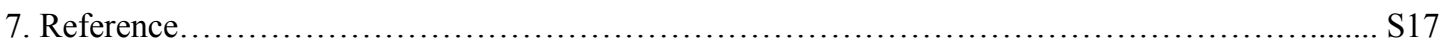




\section{Description of specially made UV-Cells}

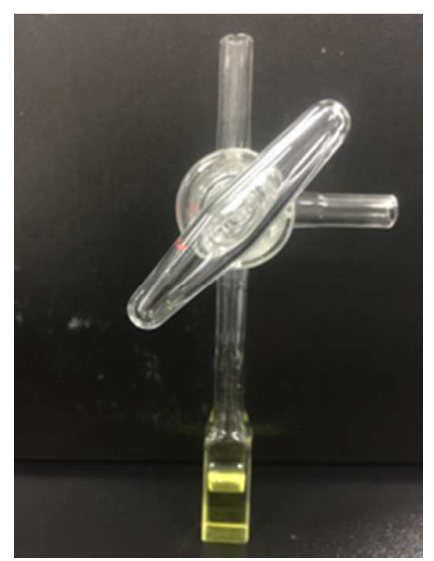

Figure S1. A picture of specially made 3-way valve UV cell, the body of the cell was made from quartz. The design of the cell enables the deprotonation of indicator acids by base, and the titration of indicator anion with sulfonamides was performed under stringent argon protection.

\section{Expanding the indicator acidity scale.}

To extend our indicator acidity scale to a more acidic region, several picric derivatives $(\mathbf{B}, \mathbf{C}, \mathbf{D}$ in Scheme $\mathrm{S} 1)$ with appropriate $\mathrm{p} K_{\mathrm{a}} \mathrm{s}$ were chosen as the indicator acids. Through constructing the acidity ladder, the indicator acidity scales were successfully extended to a more acidic region which is about $3.4 \mathrm{p} K$ units wider than that previous established by using only carbon acid indicators ${ }^{[1]}$ in $[\mathrm{BMPY}]\left[\mathrm{NTf}_{2}\right]$ and [BMIM] $\left[\mathrm{NTf}_{2}\right]$ (Scheme S1). It is worth noting that the absolute $\mathrm{p} K_{\mathrm{a}}$ of anchor compound, such as 4nitrophenylmalononitrile (A) was determined by its self-dissociation in ILs previously. ${ }^{[1]}$ Similarly, in this work the acidities of picric derivatives $(\mathbf{B}, \mathbf{C}, \mathbf{D})$ were also measured by this way (Scheme S2 gives an example), therefore all the acidities obtained by using indicator overlapping method in this work are absolute values in essence. 

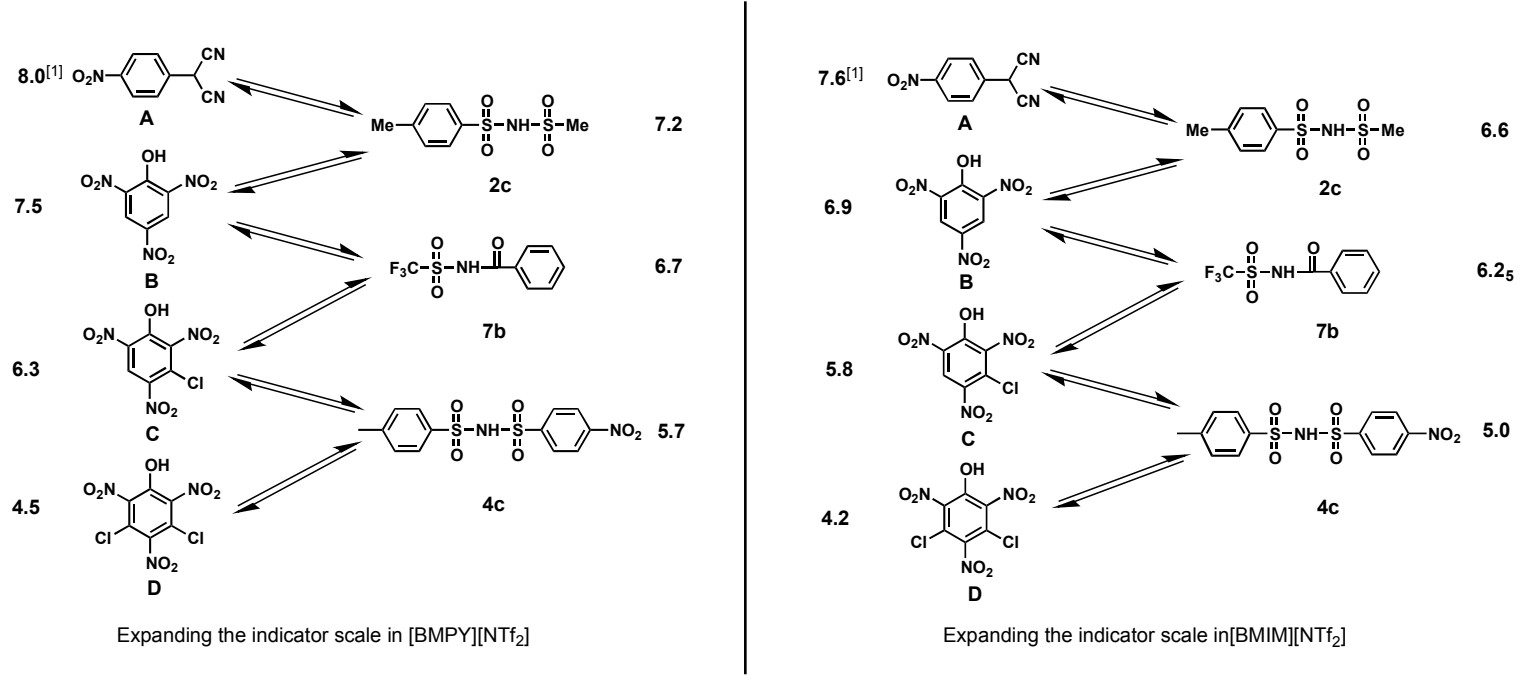

Scheme S1. Acidity ladder constructed for expanding the indicator $\mathrm{p} K_{\mathrm{a}}$ scales in ILs ( $\mathrm{SD} \leqslant \pm 0.05 \mathrm{p} K$ unit)

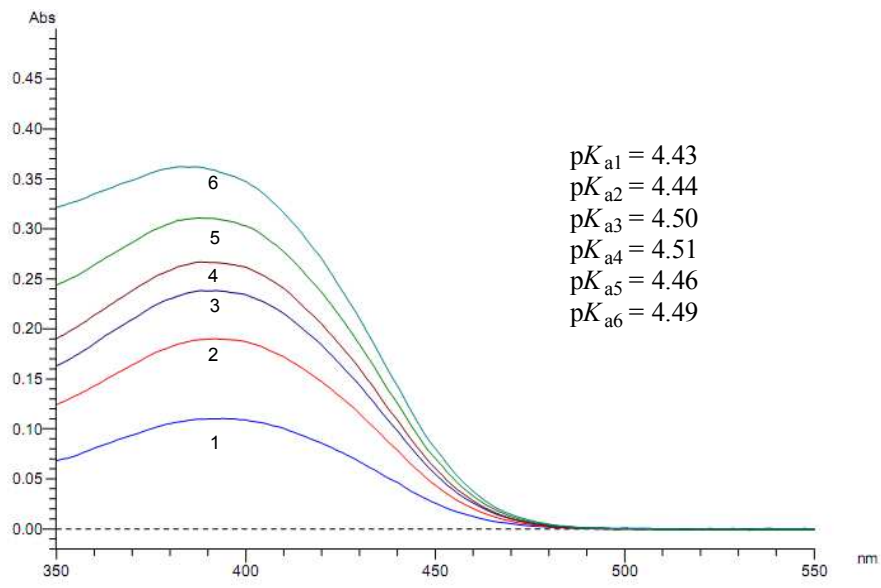

Scheme S2. The $\mathrm{p} K_{\mathrm{a}}$ measurement of an anchor compound, 3, 5-dichloropicric acid (D) by self-dissociation method in $[\mathrm{BMPY}]\left[\mathrm{NTf}_{2}\right]$.

\section{The base and indicators used in this work.}

a. The base (Figure S2) used to deprotonate indicator acids (HIn) was synthesized according to the previous introduced, ${ }^{[1][2]}$ the base was dissolved in DMSO or ILs to make a stock solution and was stored in a glove box.
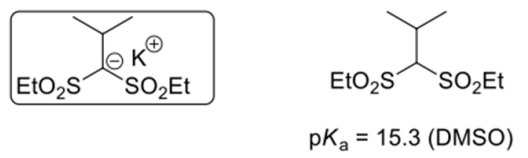

Figure S2. The base (a carbanion potassium salt) used in this work and its conjugated acid. Note that the salt is 
not ion-paired in IL solutions, as the measured $\mathrm{p} K_{\mathrm{a}}$ of substrate doesn't vary by adding a potassium chelating agent (Circa $10^{-4} \mathrm{M}$ in IL), cryptan-2,2,2 [4,7,13,16,21,24-hexaoxa-1,10-diazabicyclo-(8.8.8)-hexacosane]. ${ }^{[1]}$

b. The indicator acids used in this work were picric and carbon acid derivatives, picric acids is introduced above. The synthesis of these carbon acids were introduced previously. ${ }^{[1][2]}$ Table $\mathrm{S} 1$ lists the $\mathrm{p} K_{\mathrm{a}} \mathrm{s}$ of these carbon acid derivatives in the ILs:

Table S1. The acidities of carbon indicators acids used in this work ${ }^{[1]}$

\begin{tabular}{|c|c|c|c|c|}
\hline carbon indicator acids & $\begin{array}{c}\mathrm{p} K_{\mathrm{a}}{ }^{b} \\
{[\mathrm{Bmim}][\mathrm{OTf}]}\end{array}$ & $\begin{array}{c}\mathrm{p} K_{\mathrm{a}}{ }^{b} \\
{[\mathrm{Bmim}]\left[\mathrm{NTf}_{2}\right]}\end{array}$ & $\begin{array}{c}\mathrm{p} K_{\mathrm{a}}{ }^{b} \\
{[\mathrm{Bmpy}]\left[\mathrm{NTf}_{2}\right]}\end{array}$ & $\begin{array}{c}\mathrm{p} K_{\mathrm{a}}{ }^{b} \\
{\left[\mathrm{Bm}_{2} \mathrm{im}\right]\left[\mathrm{NTf}_{2}\right]}\end{array}$ \\
\hline 9- $\mathrm{EtSO}_{2} \mathrm{FH}^{a}$ & 17.36 & 20.25 & 20.24 & 21.14 \\
\hline $\mathrm{PhSO}_{2} \mathrm{CH}_{2} \mathrm{CN}$ & 16.65 & 19.10 & 19.35 & 19.94 \\
\hline $\mathrm{PhSO}_{2} \mathrm{CH}_{2} \mathrm{SO}_{2} \mathrm{Ph}$ & 16.42 & 18.83 & 19.24 & 19.89 \\
\hline $9-\mathrm{PhSO}_{2} \mathrm{FH}^{a}$ & 16.40 & 19.15 & 19.17 & 20.04 \\
\hline $\mathrm{p}-\mathrm{OMePhSO}{ }_{2} \mathrm{CH}_{2} \mathrm{COPh}$ & 15.47 & 18.14 & 19.06 & \\
\hline 9-COOMeFH ${ }^{a}$ & 15.32 & 18.30 & 18.36 & 19.19 \\
\hline 9-CNFH ${ }^{a}$ & 13.83 & 16.74 & 16.55 & 17.40 \\
\hline $\mathrm{p}-\mathrm{MePhSO}_{2}-2 \mathrm{PSFH}^{a}$ & 13.83 & 16.55 & 16.42 & 17.09 \\
\hline $\mathrm{p}-\mathrm{ClPhCOCH}{ }_{2} \mathrm{CN}$ & 13.68 & 16.38 & 17.01 & 17.52 \\
\hline $\mathrm{p}-\mathrm{BrPhSO}_{2}-2 \mathrm{PSFH}^{a}$ & 13.28 & 16.05 & 15.98 & 16.51 \\
\hline $\mathrm{p}-\mathrm{OmePhCH}(\mathrm{CN})_{2}$ & 11.06 & 13.72 & 13.81 & 14.26 \\
\hline $9-\mathrm{CF}_{3} \mathrm{SO}_{2} \mathrm{FH}^{a}$ & 9.99 & 12.65 & 12.63 & 13.16 \\
\hline $\mathrm{PhCH}(\mathrm{CN})_{2}$ & 9.79 & 12.45 & 12.59 & 12.96 \\
\hline $\mathrm{p}-\mathrm{ClPhCH}(\mathrm{CN})_{2}$ & 8.89 & 11.50 & 11.67 & 12.00 \\
\hline $\mathrm{p}-\mathrm{CF}_{3} \mathrm{PhCH}(\mathrm{CN})_{2}$ & 7.53 & 10.05 & 10.23 & 10.42 \\
\hline $\mathrm{p}-\mathrm{CNPhCH}(\mathrm{CN})_{2}$ & 6.40 & 8.75 & 9.05 & 9.22 \\
\hline $\mathrm{p}-\mathrm{NO}_{2} \mathrm{PhCH}(\mathrm{CN})_{2}(\mathbf{A})$ & 5.10 & 7.60 & 8.00 & 8.10 \\
\hline
\end{tabular}

$$
\mathrm{SD}=\sqrt{\frac{1}{N-1} \sum_{i=1}^{N}\left(X_{i}-\bar{X}\right)^{2}}
$$




\section{Regression analysis.}

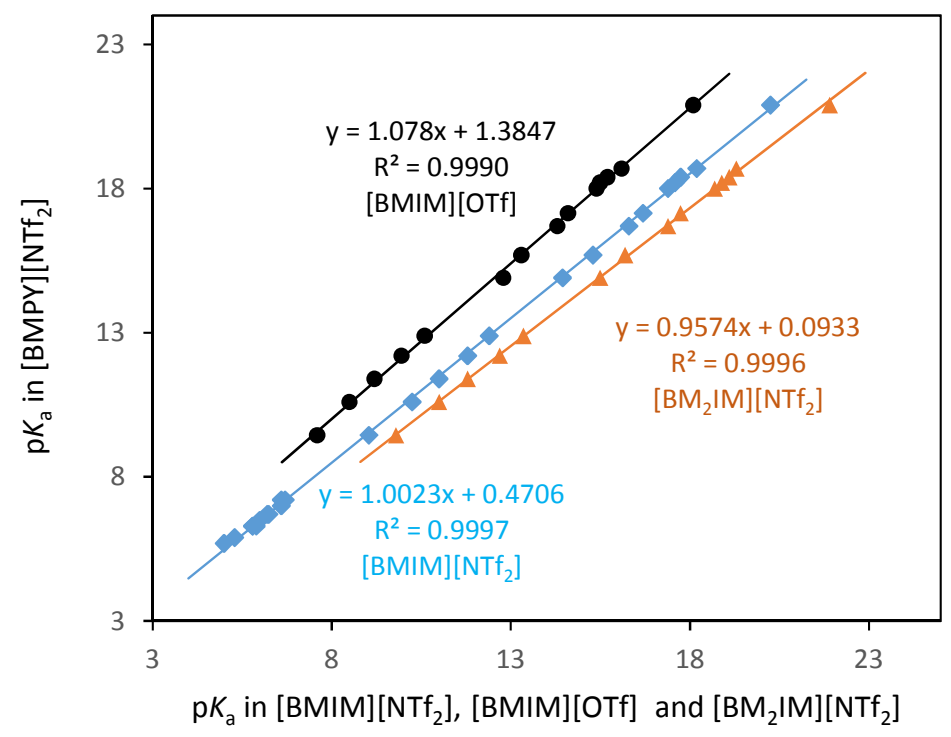

Figure S3. $\mathrm{p} K_{\mathrm{a}} \mathrm{s}$ of sulfonamides in [BMPY] $\left.\mathrm{NTf}_{2}\right]$ against these in [BMIM][NTf $\left.f_{2}\right]$, $[\mathrm{BMIM}][\mathrm{OTf}]$ and $\left.\left[\mathrm{BM}_{2} \mathrm{IM}_{[}\right] \mathrm{NTf}_{2}\right]$.

\section{Representative UV titration spectra in ILs.}

The UV-vis spectra of titration processes in ILs are similar, here only some representative spectra are given. (Figures S4-S8)

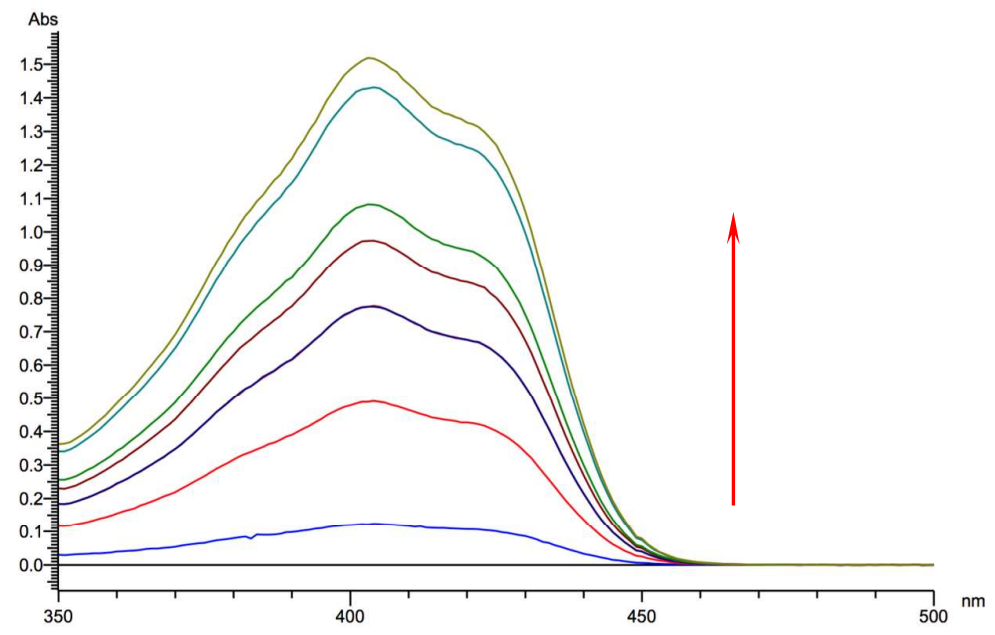

(a) 2a in $[\mathrm{BMPY}]\left[\mathrm{NTf}_{2}\right]$ 


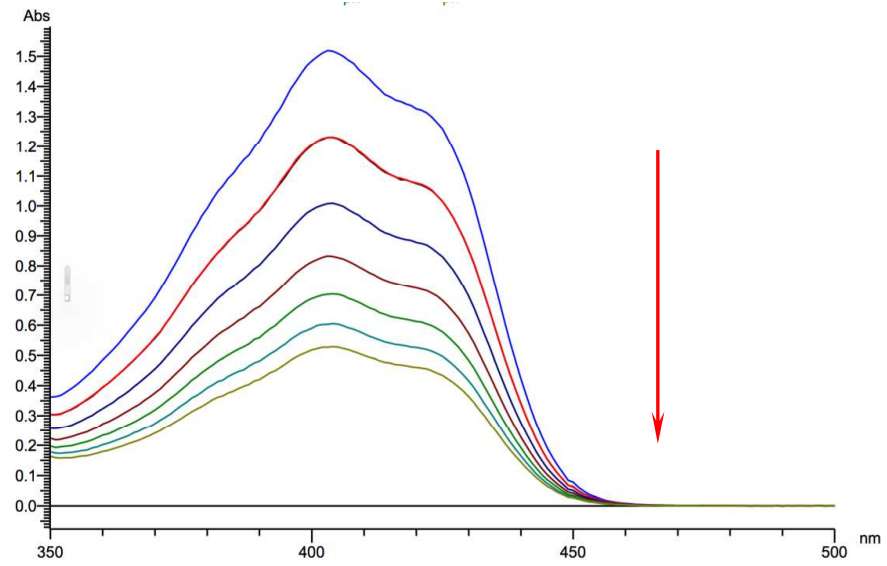

(b) 2a in $[\mathrm{BMPY}]\left[\mathrm{NTf}_{2}\right]$

Figure S4 (a) The increasing absorbance during the deprotonation of the indicator acid 9-COOMeFH by the base. (b) The decreasing absorbance during the titration of the indicator anion by $\mathbf{2 a}$ in [BMPY] $\left[\mathrm{NTf}_{2}\right]$.

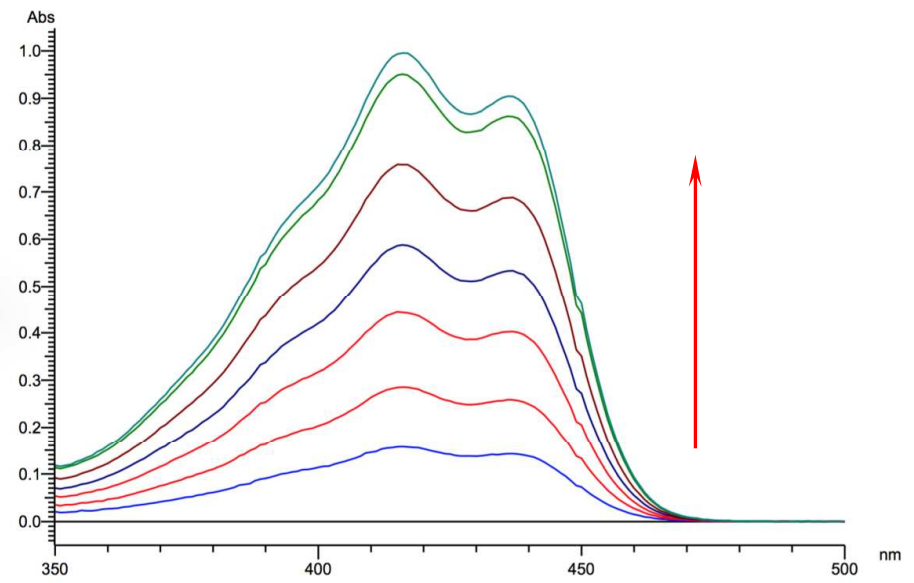

(a) $7 \mathbf{a}$ in $[\mathrm{BMPY}]\left[\mathrm{NTf}_{2}\right]$

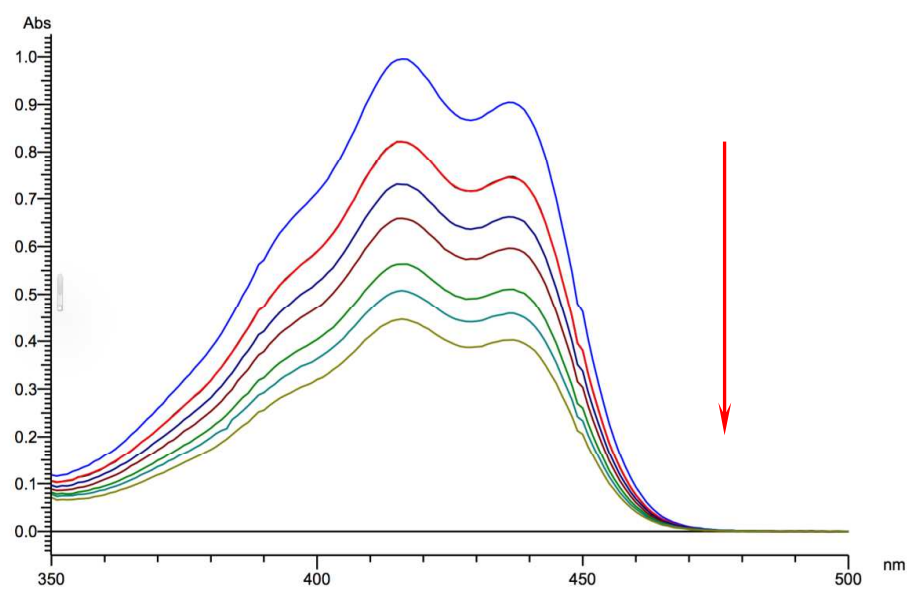

(b) $7 \mathbf{a}$ in $[\mathrm{BMPY}]\left[\mathrm{NTf}_{2}\right]$

Figure S5 (a) The increasing absorbance during the deprotonation of the indicator acid 9-CNFH by the base. (b) The decreasing absorbance during the titration of the indicator anion by $\mathbf{7 a}$ in $[\mathrm{BMPY}]\left[\mathrm{NTf}_{2}\right]$. 


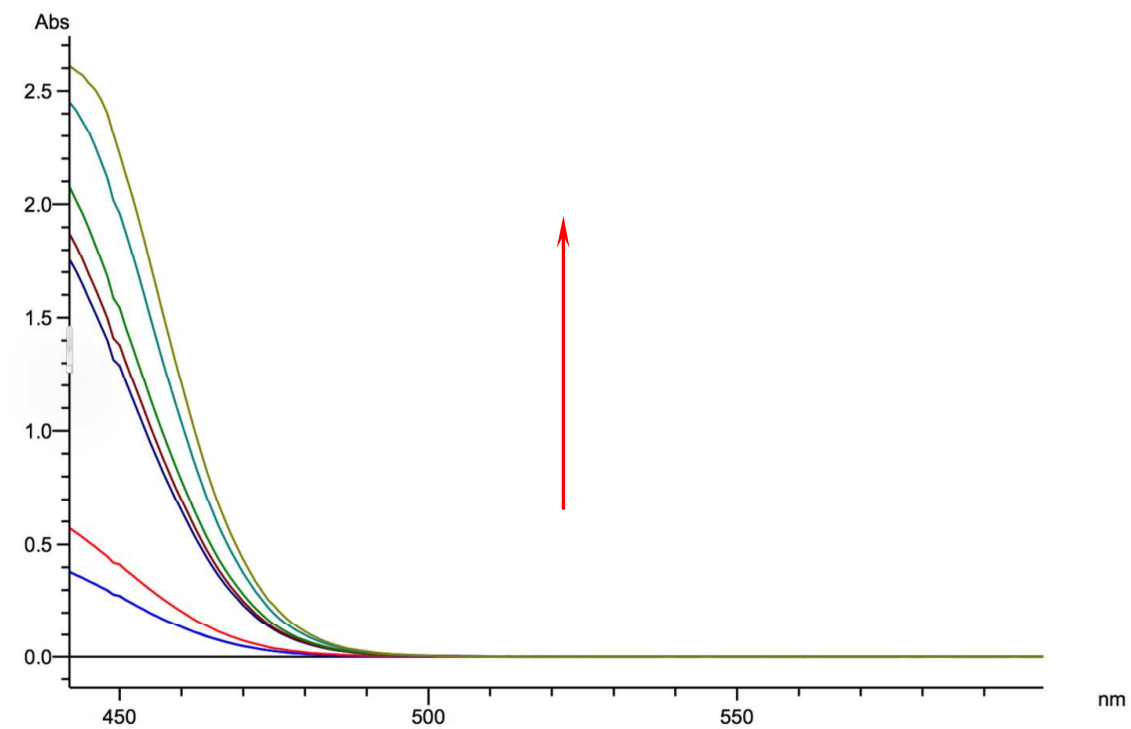

(a) $9 \mathbf{b}$ in $[\mathrm{BMIM}]\left[\mathrm{NTf}_{2}\right]$

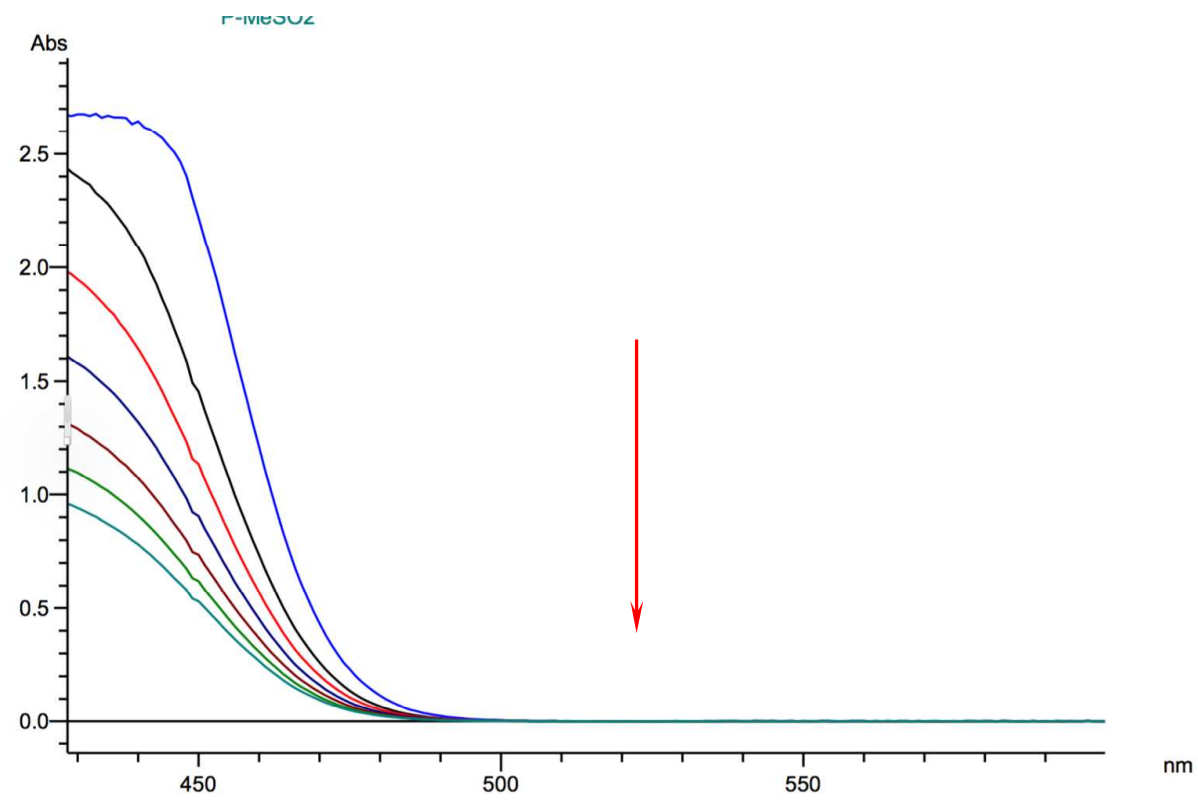

(b) $\mathbf{9 b}$ in $[\mathrm{BMIM}]\left[\mathrm{NTf}_{2}\right]$

Figure S6 (a) The increasing absorbance during the deprotonation of the indicator picric acid (B) by the base. (b) The decreasing absorbance during the titration of the indicator anion by $\mathbf{9 b}$ in [BMIM] $\left[\mathrm{NTf}_{2}\right]$. 


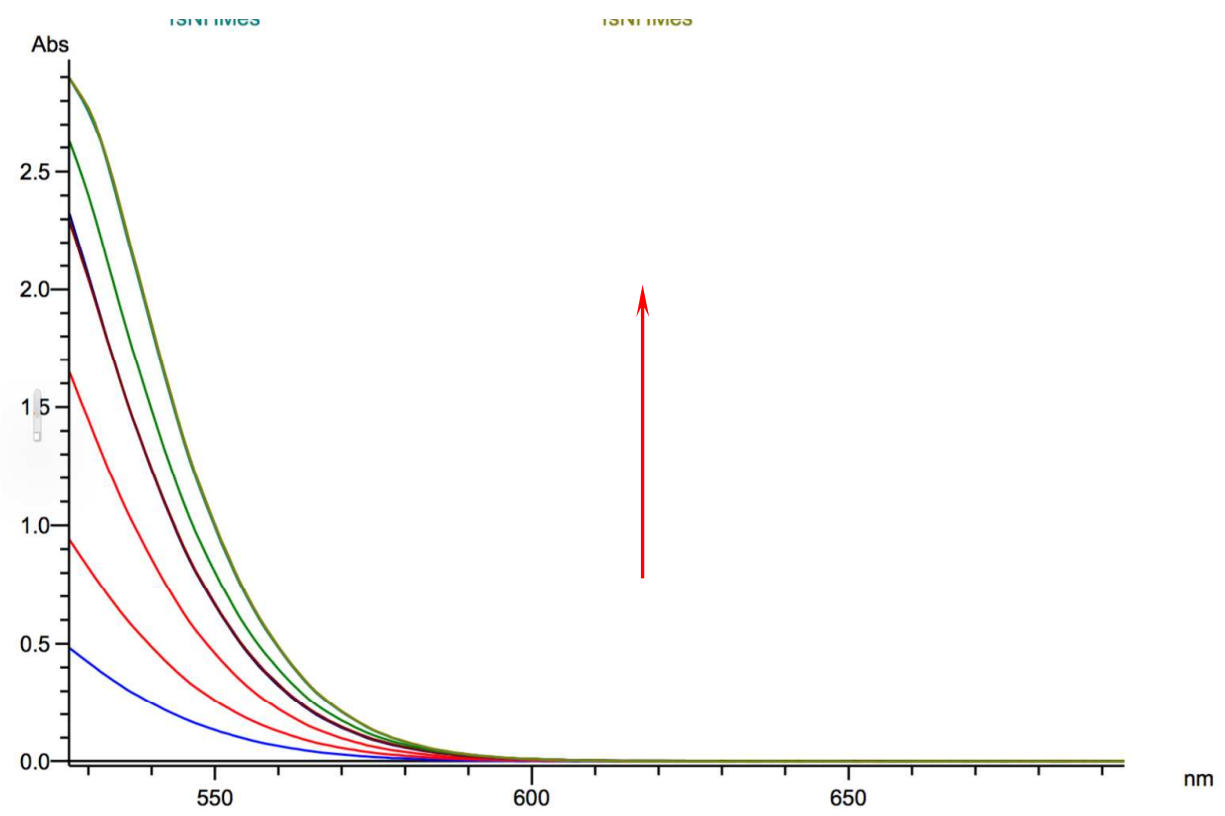

(a) $2 \mathbf{c}$ in $[\mathrm{BMPY}]\left[\mathrm{NTf}_{2}\right]$

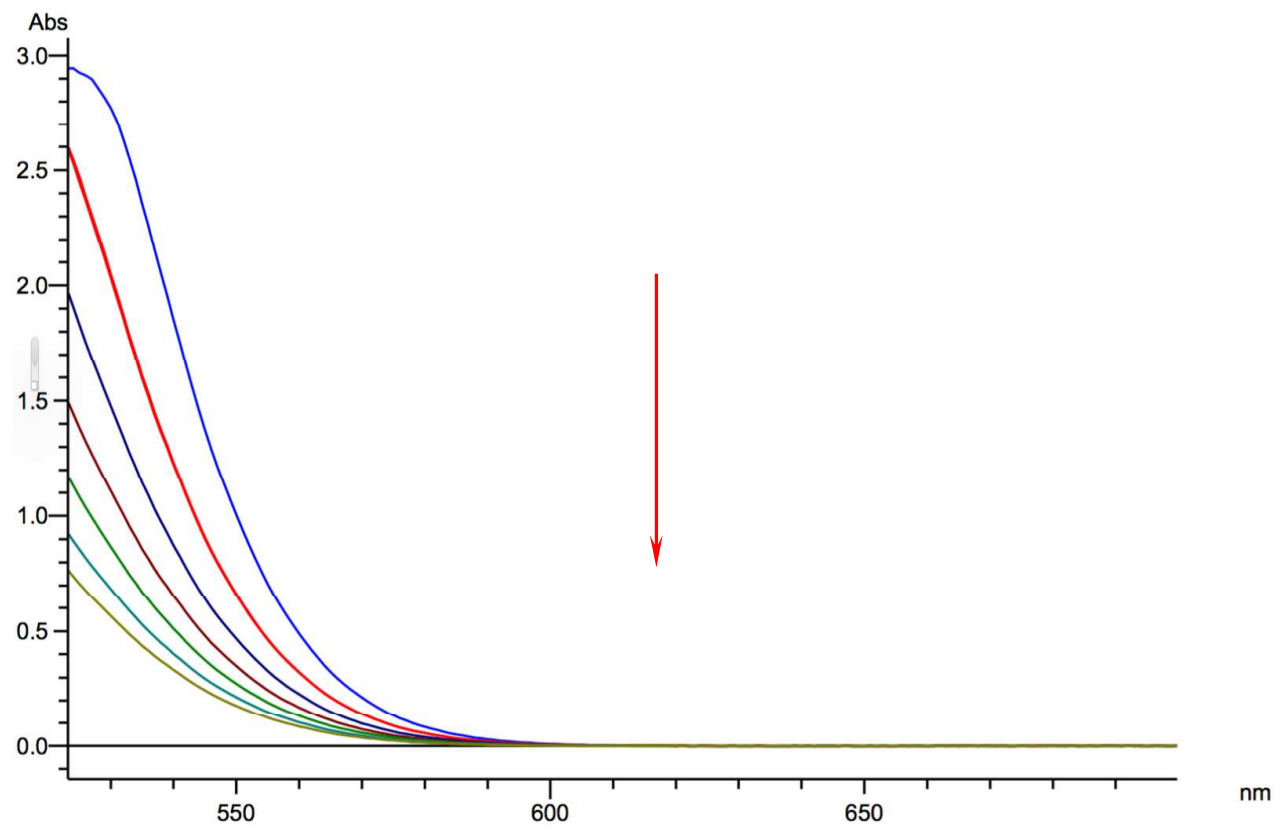

(b) $\mathbf{2 c}$ in $[\mathrm{BMPY}]\left[\mathrm{NTf}_{2}\right]$

Figure $\mathbf{S} 7$ (a) The increasing absorbance during the deprotonation of the indicator acid $\mathrm{p}-\mathrm{NO}_{2} \mathrm{PhCH}(\mathrm{CN})_{2}(\mathbf{A})$ by the base. (b) The decreasing absorbance during the titration of the indicator anion by $\mathbf{2} \mathbf{c}$ in [BMPY] $\left[\mathrm{NTf}_{2}\right]$. 


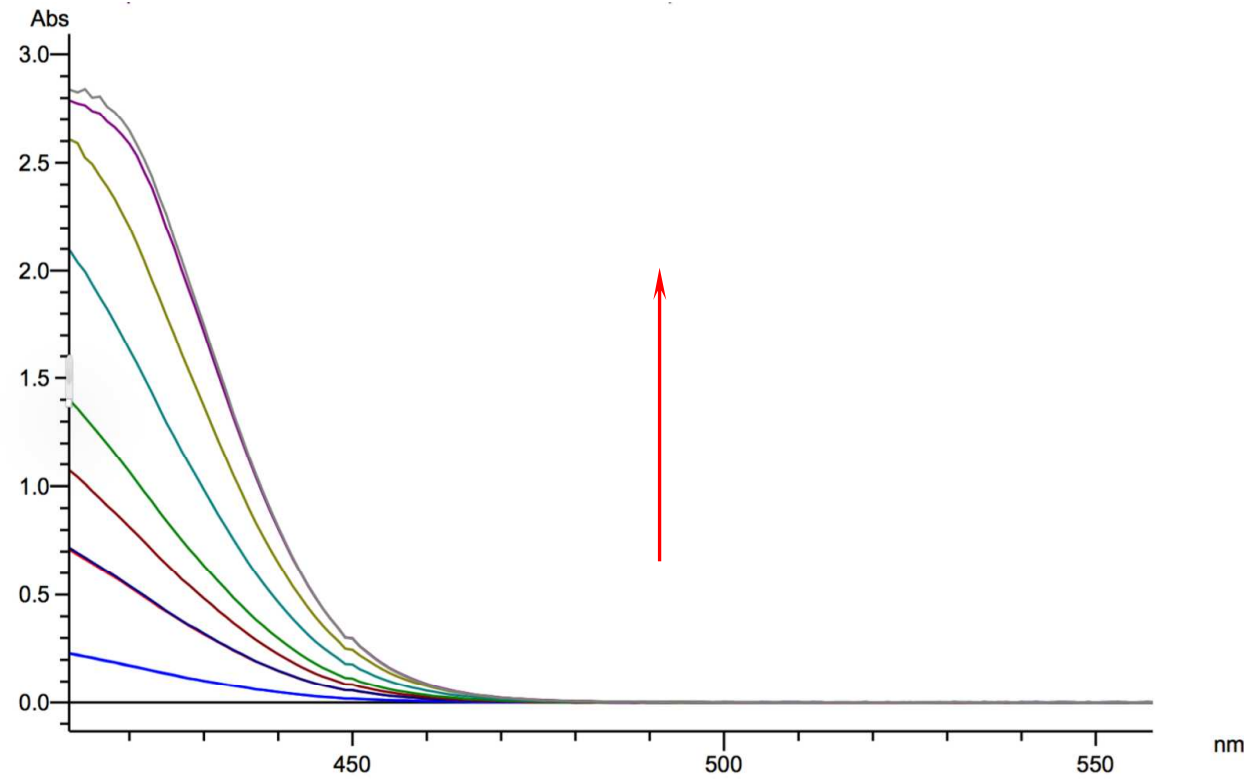

(a) $4 \mathbf{c}$ in $[\mathrm{BMPY}]\left[\mathrm{NTf}_{2}\right]$

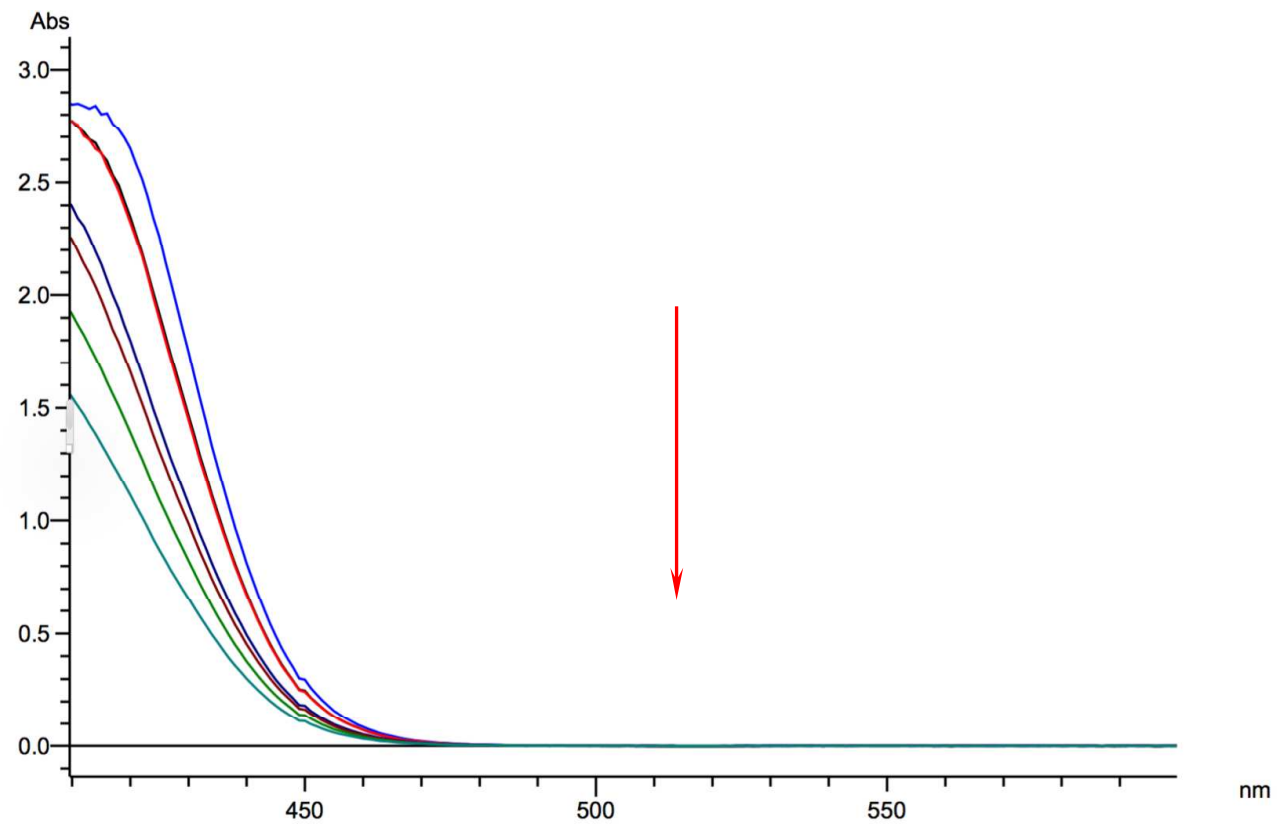

(b) $4 \mathrm{c}$ in $[\mathrm{BMPY}]\left[\mathrm{NTf}_{2}\right]$

Figure S8 (a) The increasing absorbance during the deprotonation of the indicator (A) by the base. (b) The decreasing absorbance during the titration of the indicator anion by $\mathbf{4} \mathbf{c}$ in [BMPY] $\left[\mathrm{NTf}_{2}\right]$. 
6. NMR spectra.

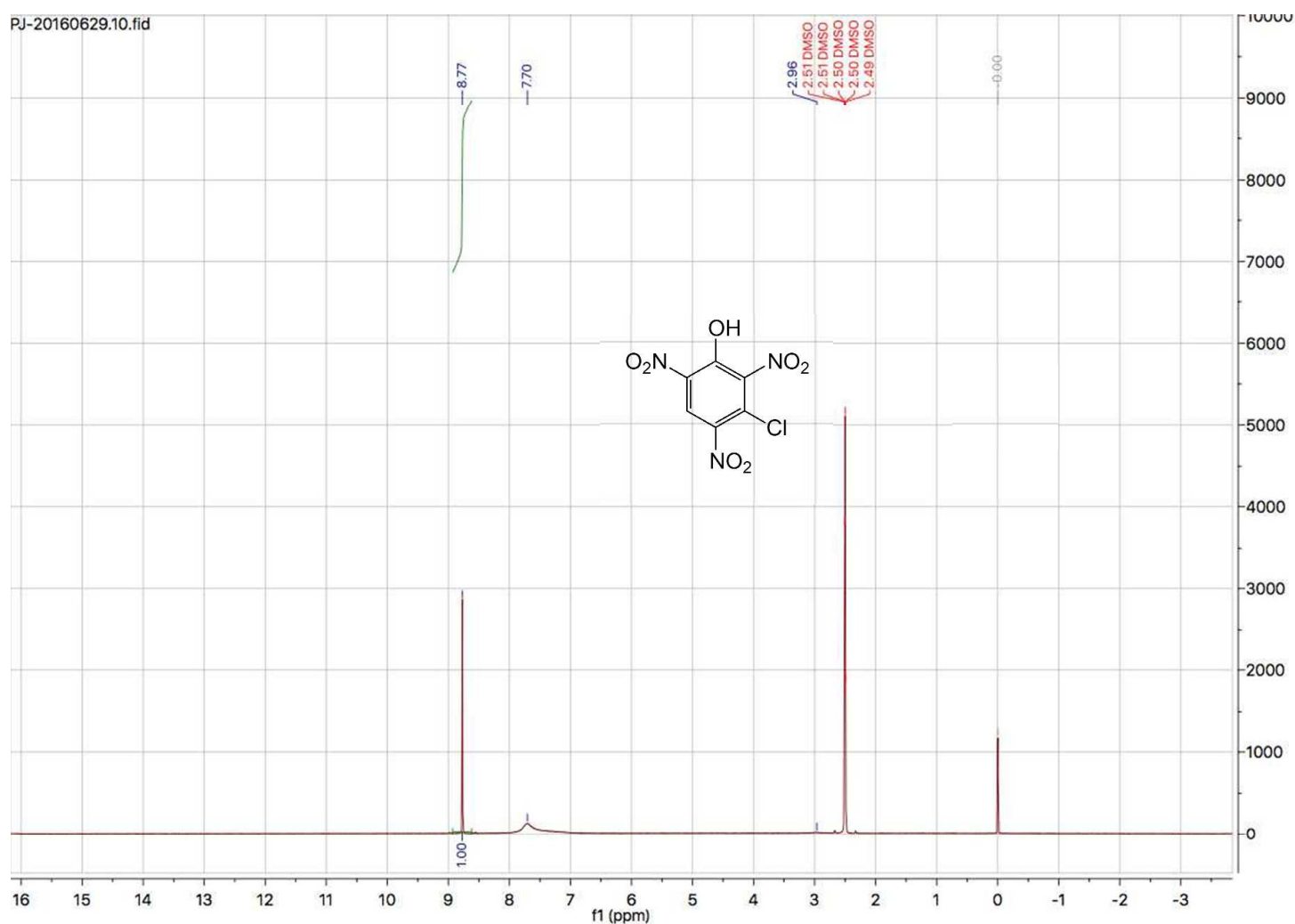

Acid indicator C (Scheme S1) ${ }^{1}$ H NMR

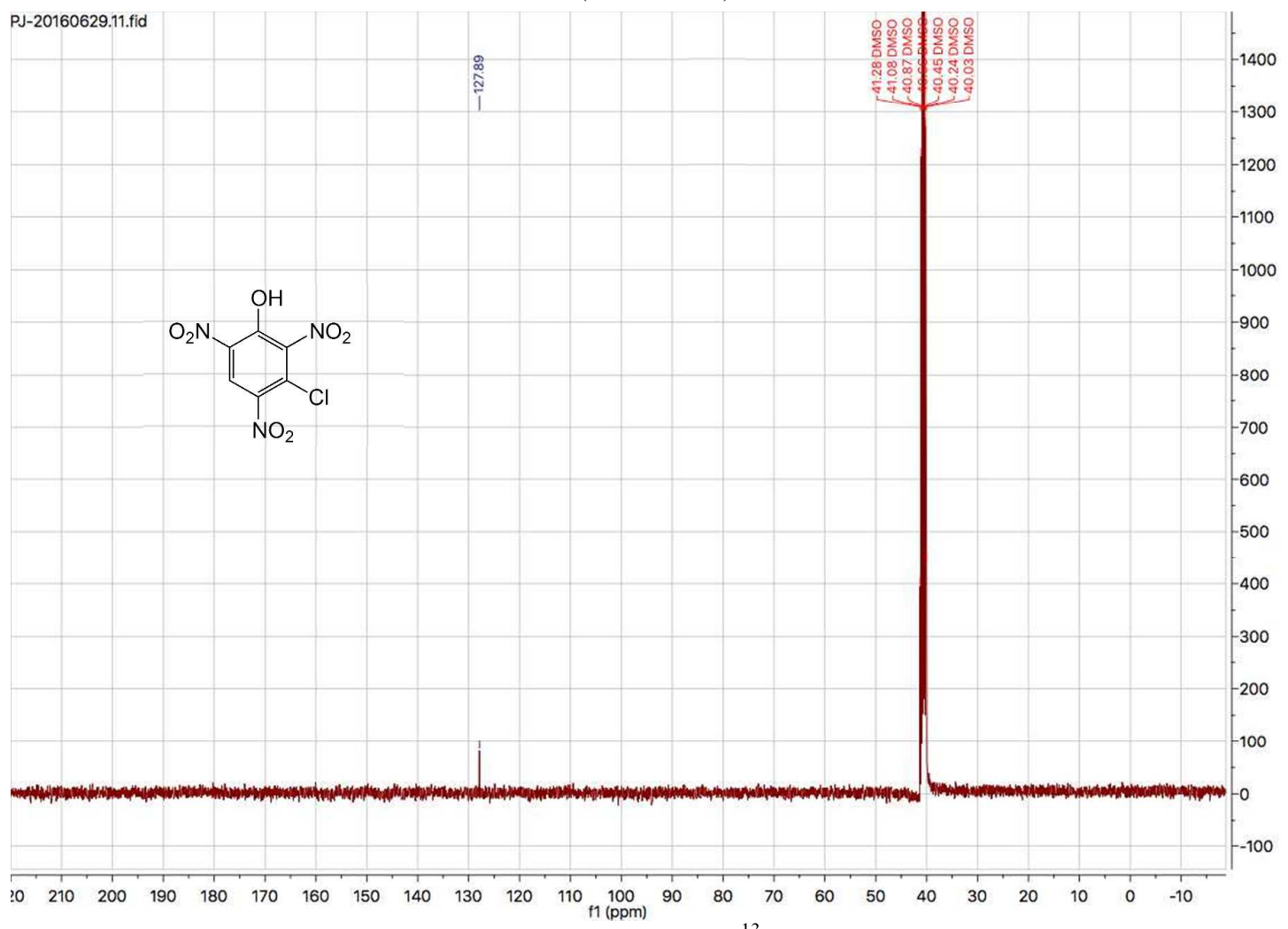

Acid indicator $\mathbf{C}$ (Scheme S1) ${ }^{13} \mathrm{C}$ NMR 


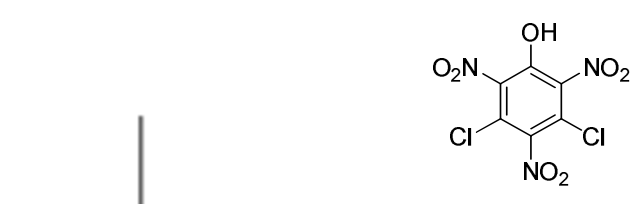

$16 \quad 14 \quad 12$

10

8

ti $\stackrel{6}{6}$

Acid indicator D (Scheme S1) ${ }^{1} \mathrm{H}$ NMR

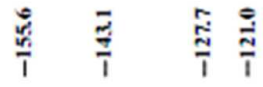

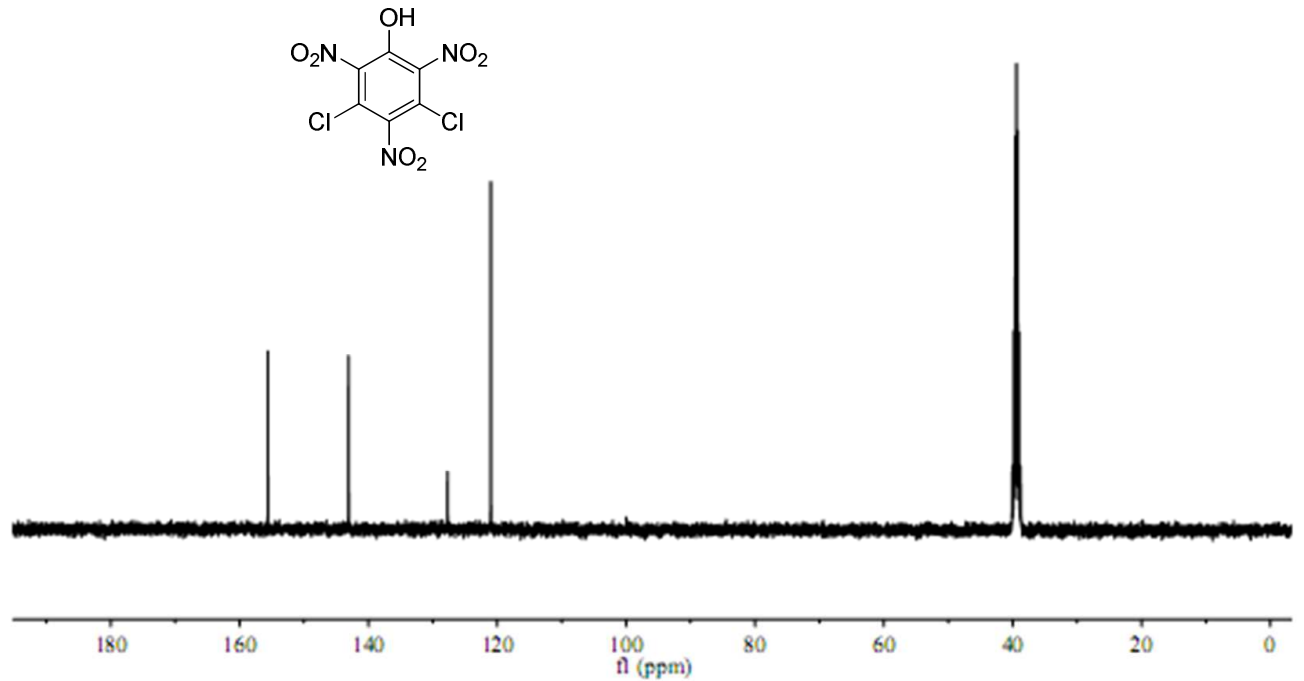

Acid indicator D (Scheme S1) ${ }^{13} \mathrm{C}$ NMR 


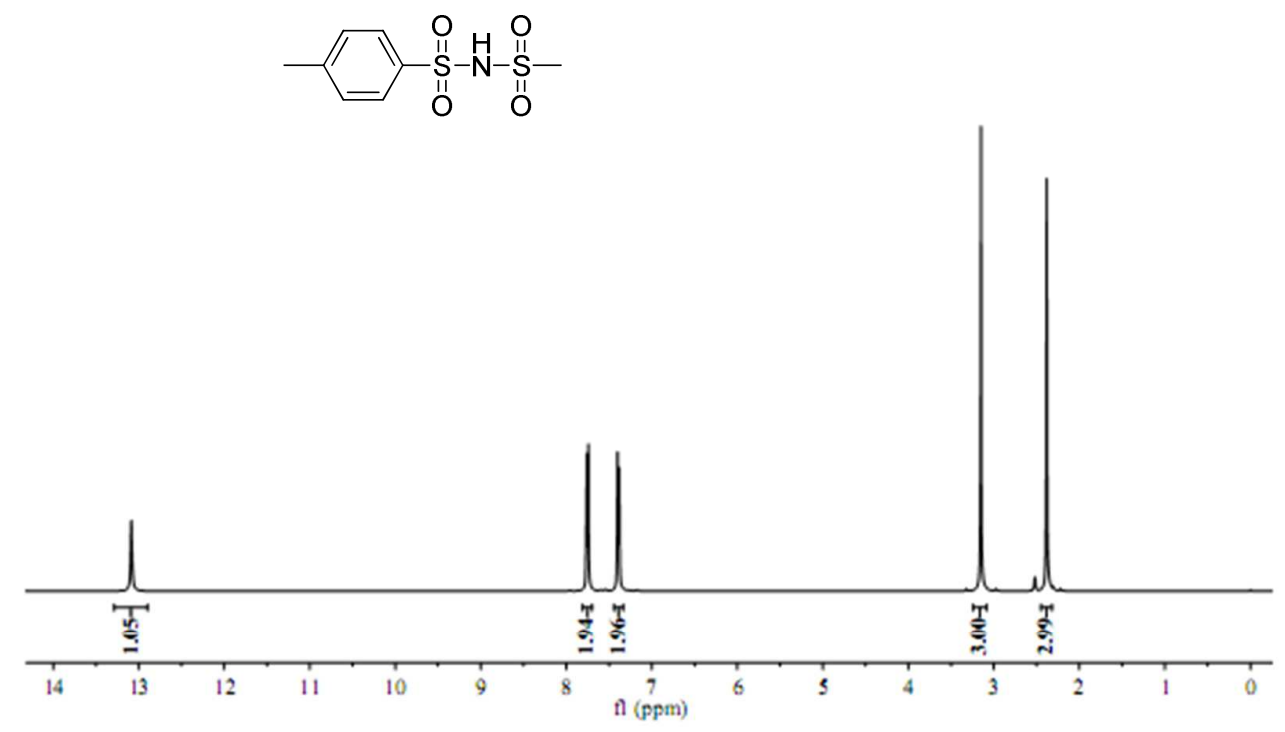

${ }^{1}$ H NMR of 2c (Scheme 2)

$\stackrel{3}{1} \frac{x}{1} \frac{0}{1}$
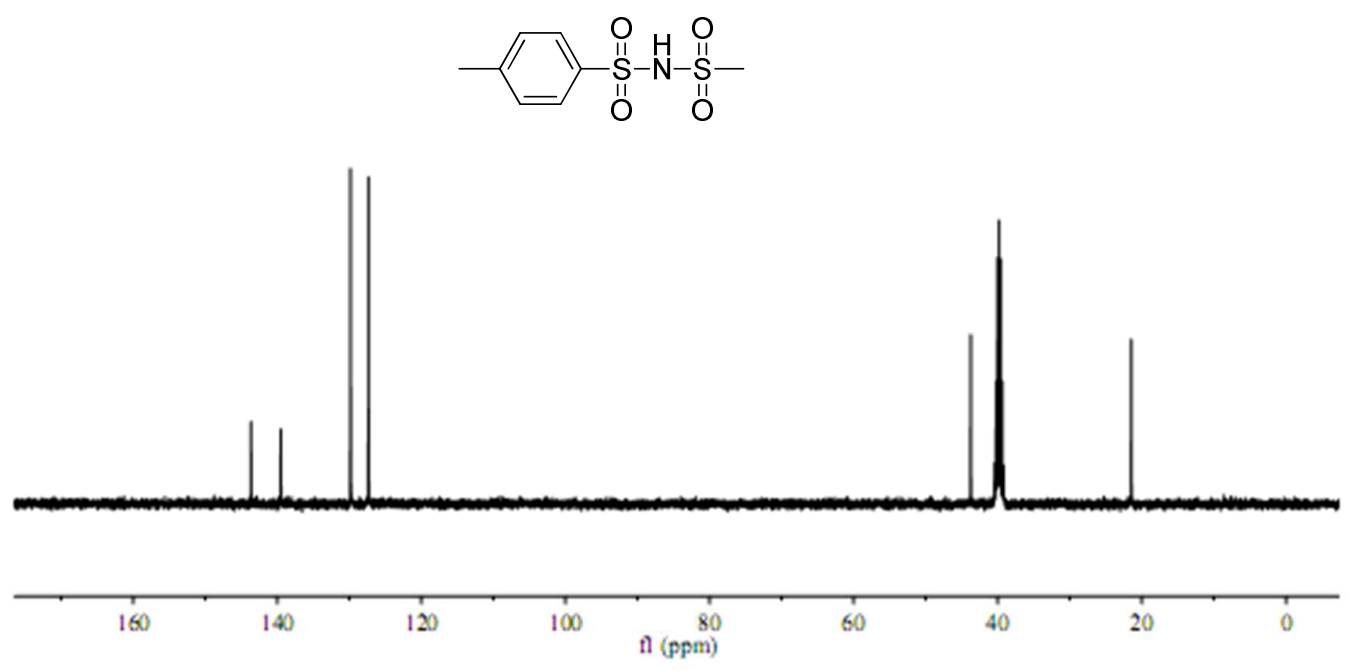

${ }^{13} \mathrm{C}$ NMR of $\mathbf{2 c}$ (Scheme 2) 

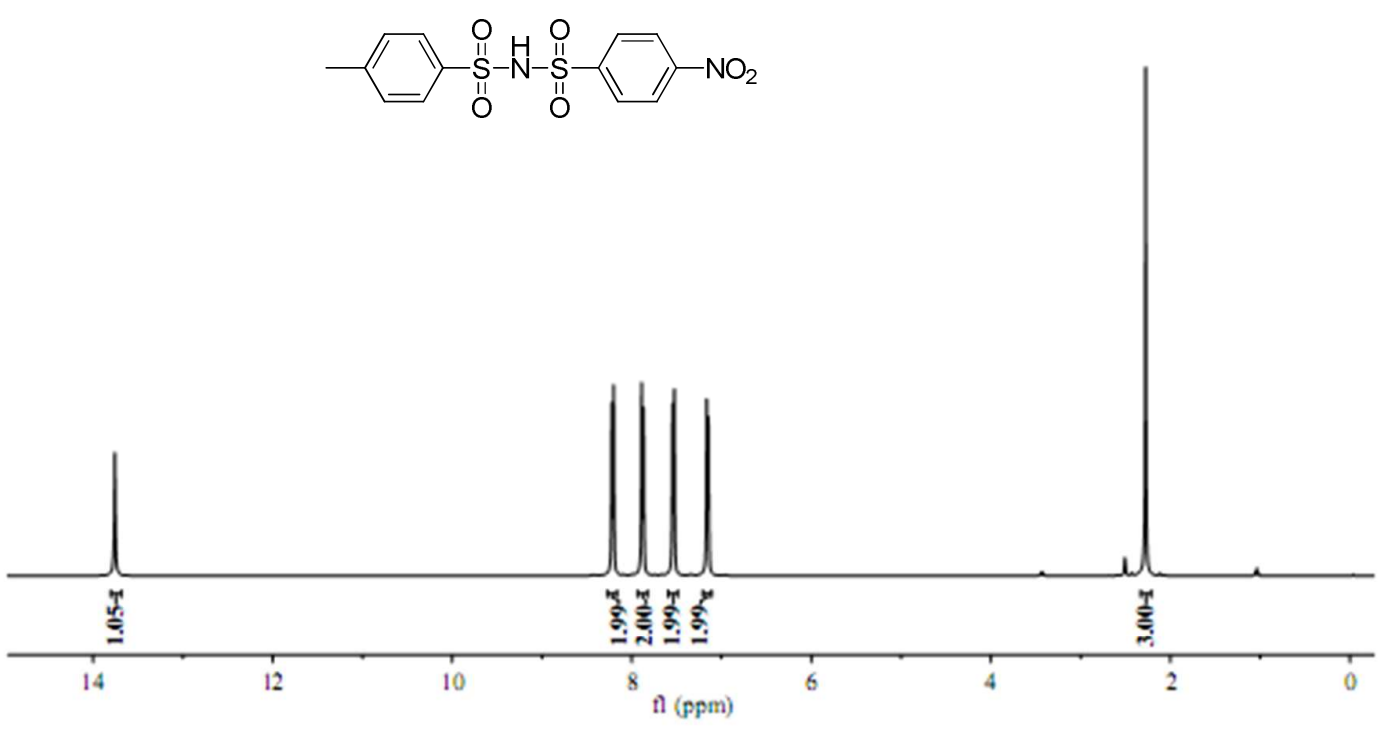

${ }^{1} \mathrm{H}$ NMR of $4 \mathbf{c}$

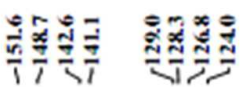
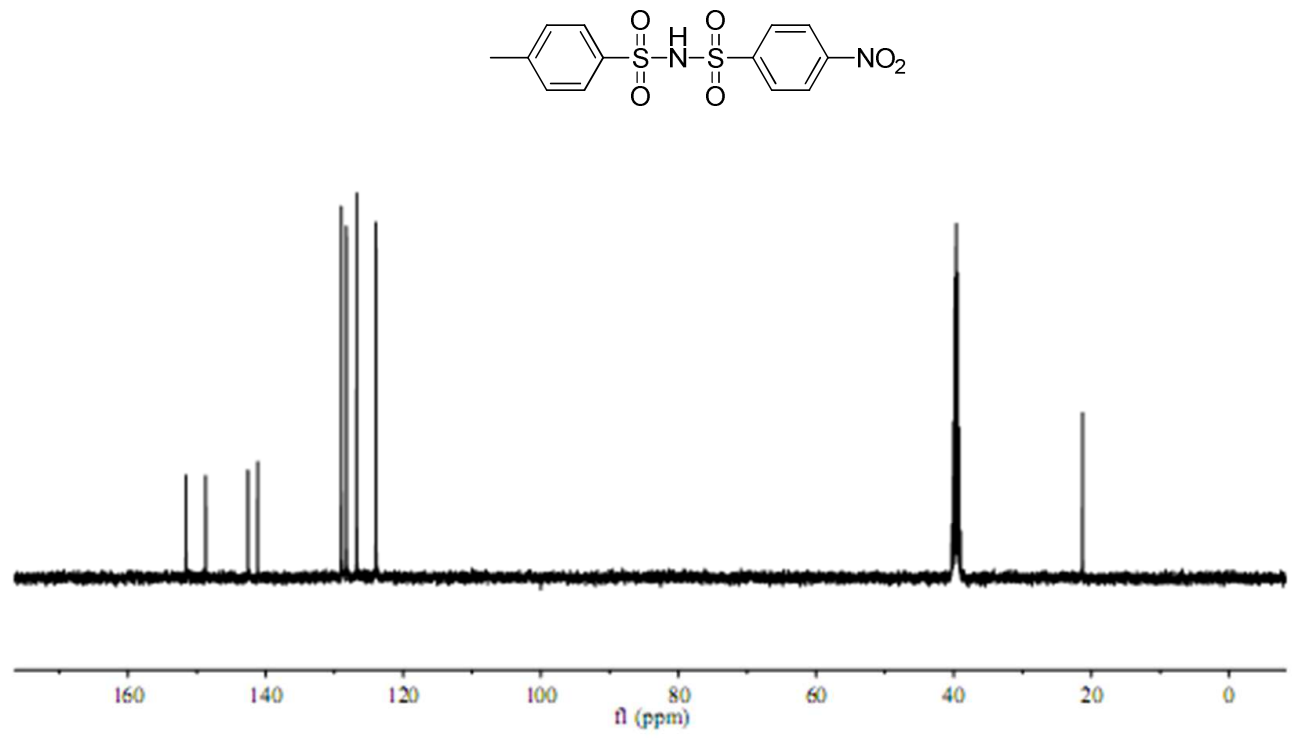

${ }^{13} \mathrm{C}$ NMR of $4 \mathbf{c}$ (Scheme 2) 

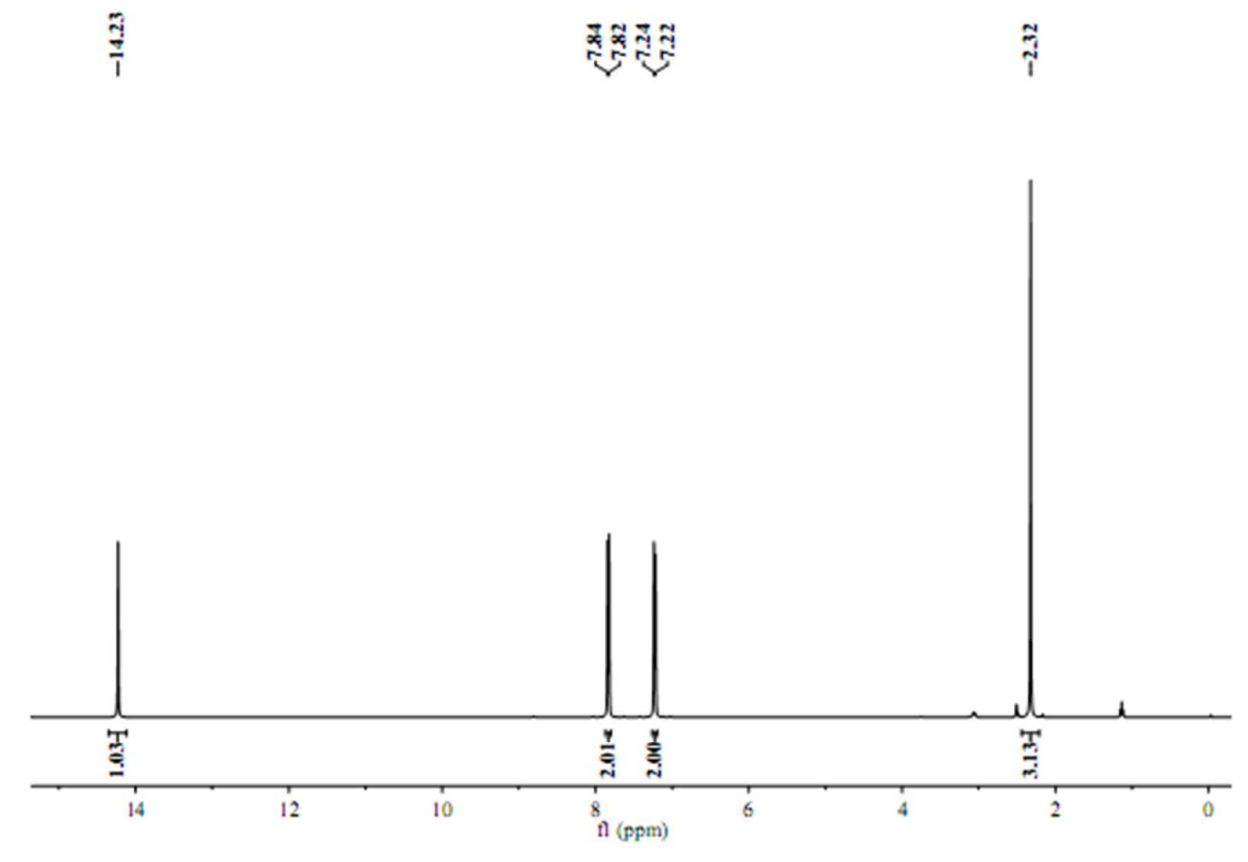

${ }^{1} \mathrm{H}$ NMR of $9 \mathbf{b}$ (Scheme 2)

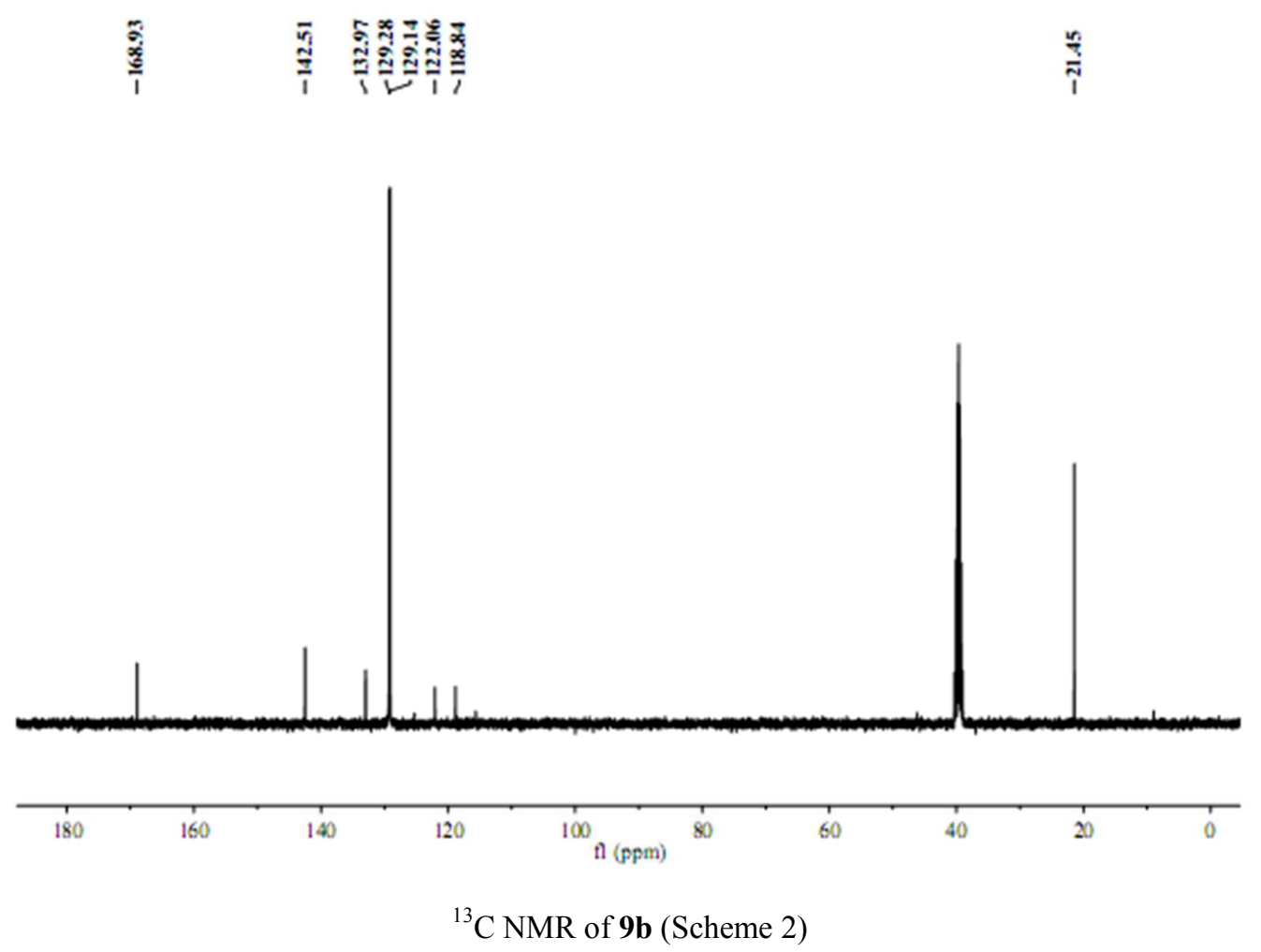




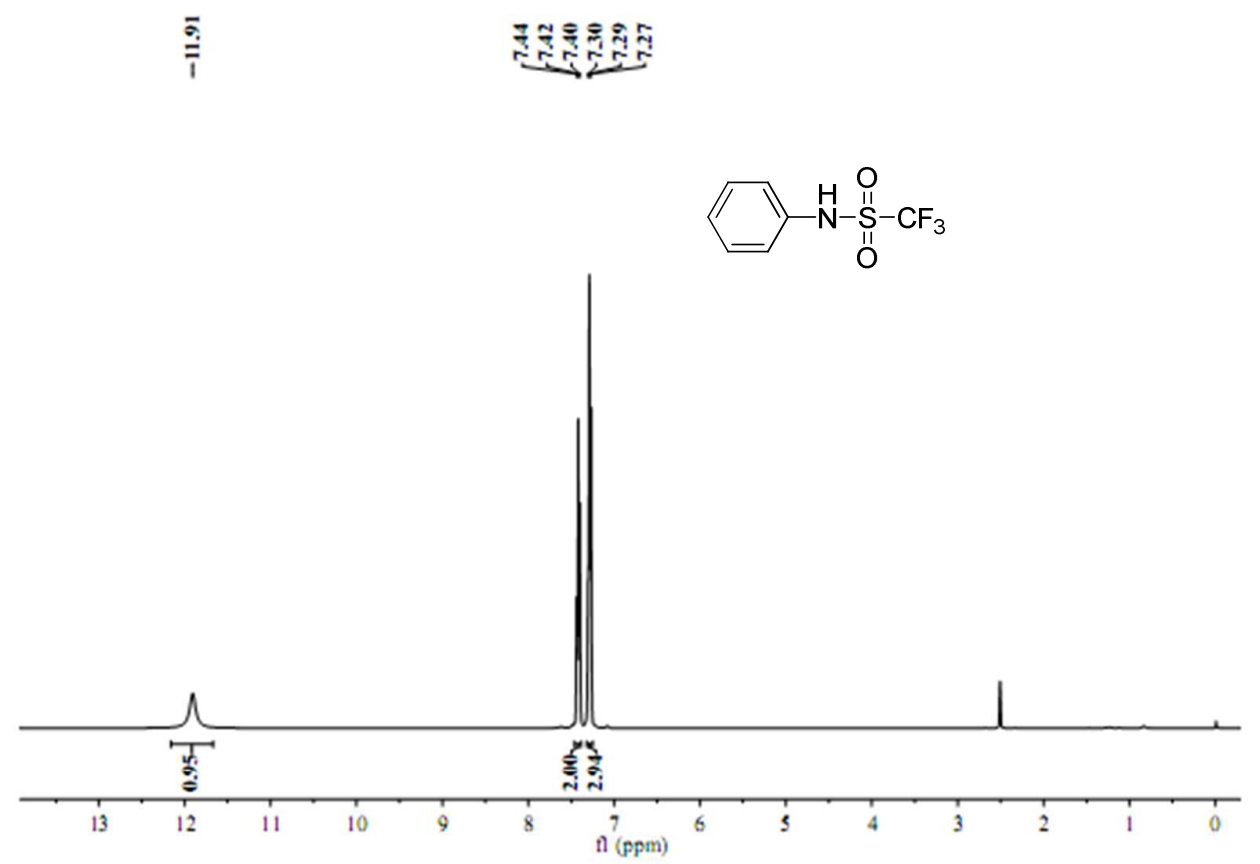

${ }^{1}$ H NMR of $\mathbf{2 b}$ (Scheme 2)

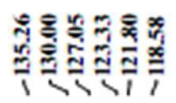

$\square-\mathrm{N}-\mathrm{S}_{\mathrm{O}}^{\mathrm{O}}-\mathrm{CF}_{3}$

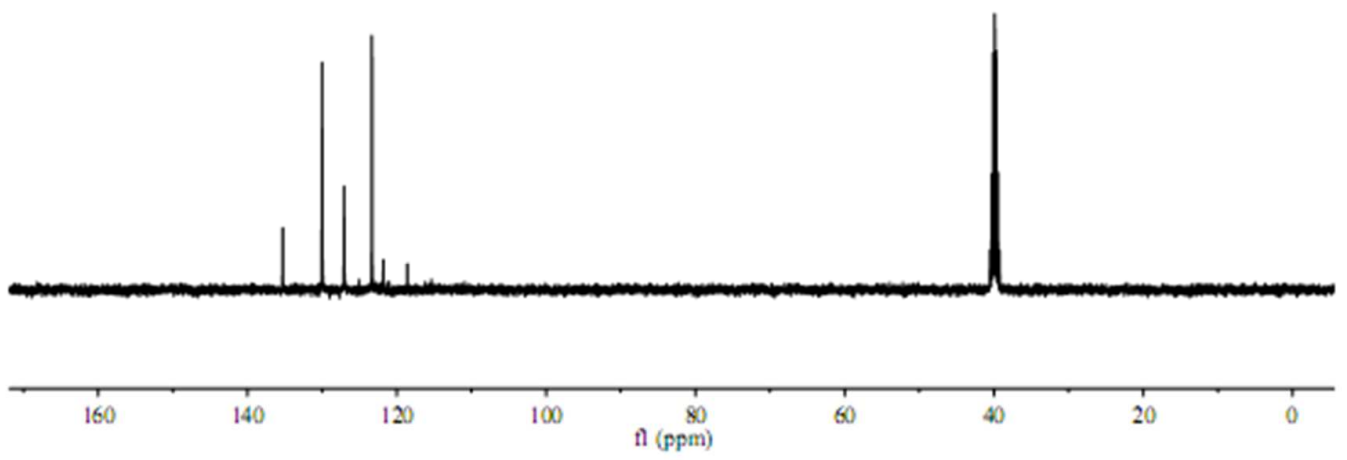

${ }^{13} \mathrm{C}$ NMR of $\mathbf{2 b}$ (Scheme 2) 


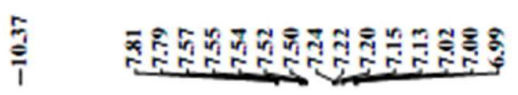

《I-

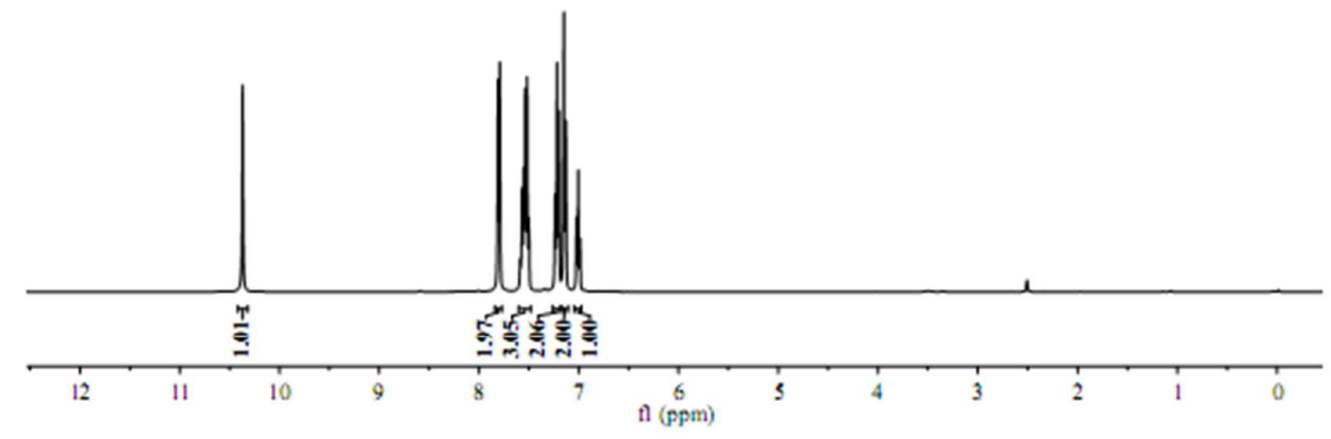

${ }^{1}$ H NMR of 2a (Scheme 2)

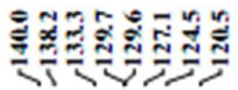
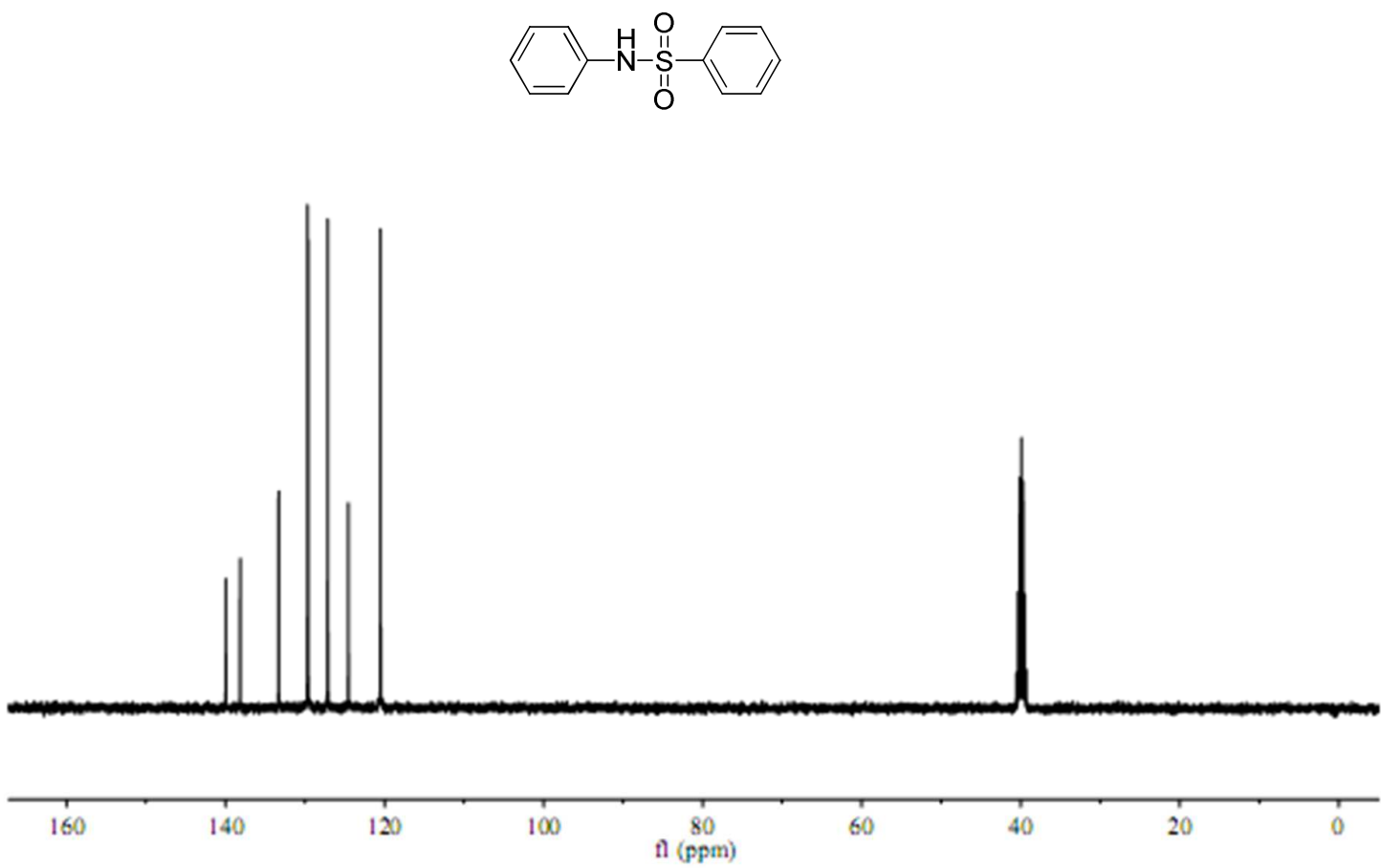

${ }^{13} \mathrm{C}$ NMR of 2a (Scheme 2) 


\section{Reference}

[1] Deng, H.; Li, X.; Chu, Y.; He, J.-Q.; Cheng, J.-P. J. Org. Chem. 2012, 77, 7291.

[2] Mao, C.; Wang, Z.-D.; Wang, Z.; Ji, P.; Cheng, J.-P. J. Am. Chem. Soc. 2016, 138, 5523. 